\title{
Comparison of Thermal Models for Ground-Mounted South-Facing Photovoltaic Technologies: A Practical Case Study
}

\author{
Henrik Zsiborács ${ }^{1}$, Gábor Pintér ${ }^{1, *}$, Attila Bai ${ }^{2}{ }^{\mathbb{D}}$, József Popp ${ }^{3}$, Zoltán Gabnai ${ }^{2}$, Béla Pályi ${ }^{4}$ (D), \\ István Farkas ${ }^{5}$, Nóra Hegedúsné Baranyai ${ }^{1}$, Christian Gützer ${ }^{6}$, Heidelinde Trimmel ${ }^{6}$, \\ Sandro Oswald ${ }^{6}$ (1) and Philipp Weihs ${ }^{6}$ \\ 1 Department of Economic Methodology, Georgikon Faculty, University of Pannonia, 8360 Keszthely, \\ Hungary; ifj.zsiboracs.henrik@gmail.com (H.Z.); baranyai@georgikon.hu (N.H.B.) \\ 2 Department of Business Economics, Institute of Applied Economics, Faculty of Economics and Business, \\ University of Debrecen, 4032 Debrecen, Hungary; bai.attila@econ.unideb.hu (A.B.); \\ gabnai.zoltan@econ.unideb.hu (Z.G.) \\ 3 Department of Agricultural Economics, Institute of Sectoral Economics and Methodology, Faculty of \\ Economics and Business, University of Debrecen, 4032 Debrecen, Hungary; popp.jozsef@econ.unideb.hu \\ 4 Department of Agricultural Mechanization, Georgikon Faculty, University of Pannonia, 8360 Keszthely, \\ Hungary; palyi@georgikon.hu \\ 5 Faculty of Mechanical Engineering, Szent István University, 2100 Gödöllő, Hungary; \\ farkas.istvan@gek.szie.hu \\ 6 Department of Water, Atmosphere and Environment, Institute of Meteorology, University of Natural \\ Resources and Life Sciences Vienna, 1180 Vienna, Austria; christian.guetzer@boku.ac.at (C.G.); \\ heidelinde.trimmel@boku.ac.hu (H.T.); sandro.oswald@boku.ac.at (S.O.); philipp.weihs@boku.ac.at (P.W.) \\ * Correspondence: pg@georgikon.hu; Tel.: +36-30-373-8550
}

Received: 6 April 2018; Accepted: 19 April 2018; Published: 2 May 2018

\begin{abstract}
This paper examines the thermal properties of free-standing, ground-installed, south-facing crystalline and amorphous silicon photovoltaic modules, the remaining energy and the energy generation of the modules, in ideal and actual summer weather conditions. This work studies the algorithms in other studies used to describe the thermal processes occurring on the surface of photovoltaic modules. Using accurate devices and real, measured data, the deviations and the inaccuracies of theoretical approaches are investigated. The emphasis of the present study is to improve the simulation accuracy of the total emitted long-wave radiation at the module surface and to show the appropriate overall convection coefficient values for ground-mounted south-facing photovoltaic technologies. The innovative aspect of the present paper is an improved model resulting from an improved convective heat transfer and net long-wave radiation calculation. As a result of this research, algorithms describing the energy fluxes were developed. These algorithms have a $1-3 \%$ better accuracy of the net long-wave radiation calculations at the module surface. The rate of net energy exchange by convection at the module surface could be improved by $10-12 \%$ compared to the previous literature.
\end{abstract}

Keywords: solar energy; PV model; heat transfer; energy analysis; efficiency

\section{Introduction}

Solar energy forms the basis of most natural processes, and provides plentiful, clean energy, which is available everywhere, even over the coming billions of years [1]. Photovoltaic solar energy uses a photovoltaic cell that transforms solar energy into electricity [2]. The rapid growth of photovoltaic 
power generation has been evident in recent years, mainly due to rapid technological development, decreasing costs, and the state subsidies introduced in many countries. In 2016, the share of renewable electricity production represented $24.5 \%$ of all electricity produced globally, of which photovoltaic technology represented $1.5 \%$. The world's built-in photovoltaic capacity (2016) is $303 \mathrm{GW}$, with the largest proportions being the European Union's $106 \mathrm{GW}$ (Germany 41.3 GW), China's 77.4 GW, Japan's $42.8 \mathrm{GW}$, and the USA's $40.9 \mathrm{GW}[3,4]$.

It can be stated that the investment costs of photovoltaic (PV) technology are now approaching the lowest cost level, whose further reduction can only be achieved by discovering new and cheaper raw materials or by developing manufacturing technology [5]. The levelized cost of electricity (LCOE) of PV panels from a $1 \mathrm{~kW}$ to $6 \mathrm{~kW}$ plant size, under Italian conditions, was calculated to be between 0.10 and $0.11 € / \mathrm{kWh}$, which is considered to be competitive compared to other green electricity technologies [6]. As regards the energy return ratio of photovoltaic technology, Leccisi et al. [7] calculated that both single-crystalline Si and multi-crystalline Si systems are able to provide a $>90 \%$ net-to-gross energy return ratio, even when deployed in less-than-optimal locations.

The amount of electricity that can be produced by PV modules depends primarily on the composition and type of the module, the combined effect of the installation, and the prevailing natural factors. Thus, losses in photovoltaic modules are influenced by, for example, reflection from the surface of the module, the recombination of charging devices, the photoelectrically inactive absorption of the photons, and when photons reach the back electrodes without producing electrons and holes. The polycrystalline and monocrystalline photovoltaic modules can reach $21.9 \%$ and $25.6 \%$ efficiency, respectively. Due to their good reliability, the current market share of crystalline solar modules is 85-90\% [1,8-16]. One type of thin film PV technology is amorphous silicon photovoltaic technology, which has $10.5 \%$ efficiency. Their market share is unknown, but the share of all thin-film solar modules is around $10-15 \%[1,10-12,16,17]$. A special type of the thin-film technology, called dye-sensitized solar cells, have an important role in renewable energy-related research activity due to their features and low-cost manufacturing processes [18]. Research projects in Hungary were conducted with silicon-based thin film and crystalline photovoltaic technologies which have been rapidly expanding, are relatively inexpensive, and have a growing market share.

An important factor in the photovoltaic modules is temperature fluctuation due to changes in temperature and solar irradiance. At the study site of the present study which is situated in Keszthely in Hungary, the photovoltaic modules can reach up to $60-65{ }^{\circ} \mathrm{C}$ on warmer days. Due to the heating of the photovoltaic module, its energy production decreases, affecting the total energy production of the PV system [19-22].

Zsiborács et al. [1] and Chandrasekar et al. [19] have shown that, in crystalline solar modules, a $1{ }^{\circ} \mathrm{C}$ increase in temperature typically results in a $0.5 \%$ reduction in efficiency, which also confirms the results $\left(0.5 \% /{ }^{\circ} \mathrm{C}\right)$ of Radziemska and Klugmann [23]. According to Skoplaki and Palyvos [20,21], it can be stated that due to the relationship between efficiency and temperature, crystalline modules have a $0.3-0.5 \%$ efficiency loss when the temperature increases by $1{ }^{\circ} \mathrm{C}$. According to Krauter [24] and Abdolzadeh and Ameri [25], the energy change-temperature relationship is $0.4-0.5 \% /{ }^{\circ} \mathrm{C}$ for the same technology.

For the sake of completeness it should be noted that in the case of an unglazed photovoltaic/thermal (PVT) solar collector, the decrease in the electrical efficiency is linear and equal to 0.015 when the temperature was between $25^{\circ} \mathrm{C}$ and $34^{\circ} \mathrm{C}$, and solar radiation increased from 100 to $1000 \mathrm{~W} / \mathrm{m}^{2}$ [26].

According to Zsiborács et al. [16], with new and 11 year-old amorphous silicon photovoltaic modules with optimum environmental conditions, orientation, and average power, using either non-networking or networking a-Si panels or string modules, a $1{ }^{\circ} \mathrm{C}$ decrease in temperature results in an average unit increase in the efficiency of energy production of $0.27 \%$. These results are similar to those of Chandrasekar et al. [16] $\left(0.21 \% /{ }^{\circ} \mathrm{C}\right)$ and confirm the results of Skoplaki and Palyvos $[20,21]$ $\left(0.2-0.3 \% /{ }^{\circ} \mathrm{C}\right)$. 
For crystalline and amorphous silicon photovoltaic modules, there is a linear change in the level of temperature efficiency and the temperature energy change (from $-48{ }^{\circ} \mathrm{C}$ to $+85^{\circ} \mathrm{C}$ ) $[20,21,27]$. The change in the incoming solar irradiance is closely related to temperature change. The energy production of PV modules in shade-free, clear conditions is predominantly influenced by two factors, namely, incoming solar irradiance and temperature $[20,21]$.

In the present study extensive measurements for the determination of the various energy fluxes were performed.

\section{Materials and Methods}

\subsection{Thermal Dynamics for Photovoltaic Modules}

In this study, the tilt angle-orientation of the crystalline and amorphous silicon solar modules and their dual-axis tracking characteristics and energy production were investigated in summer, in real and ideal weather conditions near to the summer solstice, compared to simulated data. The aim was to clarify the total emitted long-wave radiation at the module surface $\left(\mathrm{Q}_{1 \mathrm{l}, \text { total }}\right)$ and to show the appropriate overall convection coefficient $\left(\mathrm{h}_{\text {conv }}\right.$ ) values for ground-mounted south-facing photovoltaic technologies. The innovative aspect of the present paper consists of an improved model including more accurate algorithms for convective heat transfer and net long wave radiation calculation. This work focuses primarily on physical relationships and the physical description of the energetic processes. The thermal processes of PV modules have been subject to a number of analyses [28-33]. However, all algorithms differ one from another, regardless of the installation structure and produce different end results. The most striking difference is found for the emitted long-wave radiation at the module surface and for the convective heat transfer on the PV module surface. There is, therefore, a need for additional experiments under real outdoor conditions to improve the characterization and better determine the thermal characteristics of PV module systems. The main component of the heat balance of PV modules is the solar radiation which, in turn, influences convective heat exchanges, radiative heat exchanges, and the output power of the PV module, while the significance of conduction is minimal, i.e., it can easily be neglected [28-30].

The heat balance of the solar module is given by Jones and Underwood, Tsai and Tsai, and Tsai $[28,30,31]$ :

$$
\mathrm{m}_{\mathrm{pv}} \mathrm{C}_{\mathrm{pv}} \dot{\mathrm{T}}_{\mathrm{pv}}=\mathrm{Q}_{\mathrm{sw}}-\mathrm{Q}_{\mathrm{lw}, \text { total }}-\mathrm{Q}_{\mathrm{conv}}-\mathrm{P}_{\mathrm{pv}},
$$

or the relationship can also be interpreted as follows: Zsiborács et al. [33]:

$$
\mathrm{Q}_{\mathrm{rem}}=\mathrm{Q}_{\mathrm{sw}}-\mathrm{Q}_{\mathrm{lw}, \text { total }}-\mathrm{Q}_{\mathrm{conv}}-\mathrm{P}_{\mathrm{pv}}
$$

where $\mathrm{m}_{\mathrm{pv}}, \mathrm{C}_{\mathrm{pv}}$, and $\dot{\mathrm{T}}_{\mathrm{pv}}$ are the mass, heat capacity, and temperature of the PV module. The $\mathrm{Q}_{1 \mathrm{w}, \text { total }}$ is the total emitted long-wave radiation at the module surface (which is the sum of the net longwave radiation of the top and the bottom sides of the PV modules), the $Q_{s w}$ is the effective irradiation on the $\mathrm{PV}$ module, the $\mathrm{Q}_{\text {conv }}$ is the convective heat transfer on the PV module, and $\mathrm{P}_{\mathrm{pv}}$ is the output power by the module. Qrem is the remaining heat of the PV module.

To determine the amount of heat absorbed from the heat arriving at the PV module from solar radiation per unit of surface area in each unit of time, the PV module surface area $\left(A_{p v}\right)$, the PV module absorptivity $(\alpha)$ and incoming solar irradiance $(G)$ must be known [28-32]:

$$
\mathrm{Q}_{\mathrm{sW}}=\alpha \mathrm{GAPV}
$$

The absorption values for crystalline PV modules are reported by van Helden et al. [34] as 0.78, by Jones and Underwood [28] as 0.77, while Tsai and Tsai [30] reports a wider distribution of $0.70-0.80$. Santbergen and van Zolingen [35] records a value of 0.81 for amorphous silicon photovoltaic modules. 
There are several approaches to determine the emitted long-wave radiation at the top of the module surface $\left(\mathrm{Q}_{\mathrm{lw}, \mathrm{up}}\right)$.

According to Jones and Underwood [28], at the PV module surface this relationship may be described as follows:

$$
\mathrm{Q}_{\mathrm{lw}, \text { up }}=\mathrm{A}_{\mathrm{PV}} \sigma\left(\frac{\left(1+\cos \beta_{\text {surface }}\right)}{2} \varepsilon_{\text {sky }} \mathrm{T}_{\text {sky }}^{4}+\frac{\left(1-\cos \beta_{\text {surface }}\right)}{2} \varepsilon_{\text {ground }} \mathrm{T}_{\text {ground }}^{4}-\varepsilon_{\text {module }} \mathrm{T}_{\text {module }}^{4}\right) .
$$

According to Yang et al. [29], the whole relationship requires that we take into account the PV absorptivity of the given PV technology, and the difference between the upper and lower parts of the PV module, and ignore the $\frac{\left(1+\cos \beta_{\text {surface }}\right)}{2}, \frac{\left(1-\cos \beta_{\text {surface }}\right)}{2}$ relationships:

$$
\mathrm{Q}_{\mathrm{lw}, \text { total }}=\alpha \mathrm{A}_{\mathrm{PV} \sigma} \sigma\left(\varepsilon_{\text {sky }} \mathrm{T}_{\text {sky }}^{4}+\varepsilon_{\text {ground }} \mathrm{T}_{\text {ground }}^{4}-2 \varepsilon_{\text {module }} \mathrm{T}_{\text {module }}^{4}\right) .
$$

According to Tsai and Tsai [30] and Xu et al. [32], the correlation can be more simply described by overwriting the $\frac{\left(1+\cos \beta_{\text {surface }}\right)}{2}, \frac{\left(1-\cos \beta_{\text {surface }}\right)}{2}$ relationships and ignoring $\alpha$, and by simplifying $\mathrm{T}$ and $\varepsilon$ values:

$$
\mathrm{Q}_{\mathrm{lw} \text {, total }}=\mathrm{A}_{\mathrm{PV}} \sigma \varepsilon_{\text {module }}\left(\mathrm{T}_{\mathrm{amb}}^{2}+\mathrm{T}_{\text {module }}^{2}\right)\left(\mathrm{T}_{\mathrm{amb}}+\mathrm{T}_{\text {module }}\right) \text {. }
$$

A tilted surface with an inclination $\beta$ from the horizontal has a view factor of $\frac{\left(1+\cos \beta_{\text {surface }}\right)}{2}$ for the sky and $\frac{\left(1-\cos \beta_{\text {surface }}\right)}{2}$ for the horizontal ground [28,36]. Regarding the emission $(\varepsilon)$ values, Jones and Underwood [28], Yang et al. [29], and Schott [37] offer a more detailed reference:

- $\quad \varepsilon_{\text {sky }}=0.95$ for clear conditions; 1.0 for overcast conditions;

- $\quad \varepsilon_{\text {ground }}=0.95$; and

- $\quad \varepsilon_{\text {module }}=0.8-0.9$ in the case of crystalline PV modules [28-30]; 0.83-0.96 for amorphous silicon photovoltaic modules [38].

According to Jones and Underwood [28], $\mathrm{T}_{\text {sky }}=\left(\mathrm{T}_{\mathrm{amb}}-\delta \mathrm{T}\right)$ for clear sky conditions in which $\delta \mathrm{T}=20 \mathrm{~K}$, and $\mathrm{T}_{\mathrm{sky}}=\mathrm{T}_{\mathrm{amb}}$ for overcast conditions. According to Tsai and Tsai [30], Tsai [31], and $\mathrm{Xu}$ et al. [32], $\mathrm{T}_{\mathrm{sky}}=\mathrm{T}_{\mathrm{amb}}$, since during the energy exchange the direct surrounding space of the PV module is important. This is reinforced by work by Hodges [39], which calculates the air temperature experienced at a height of $2 \mathrm{~m}$. The $\sigma$ mark is the Stefan-Boltzmann's constant.

In the case of the convective heat transfer at the module, the main relationship is uniform [28-31]:

$$
\mathrm{Q}_{\text {conv }}=\mathrm{A}_{\mathrm{PV}} \mathrm{h}_{\text {conv }}\left(\mathrm{T}_{\text {module }}-\mathrm{T}_{\mathrm{amb}}\right),
$$

where $h_{\text {conv }}$ is the overall convection coefficient. The determination of the $h_{\text {conv }}$ value is possible with the following equation [28-30]:

$$
\mathrm{h}_{\mathrm{conv}}=\mathrm{h}_{\text {Force }}+\mathrm{h}_{\text {Free, }}
$$

$h_{\text {Free, }}$ and $h_{\text {force }}$ are the forced and the free convection coefficients, respectively. According to Tsai and Tsai [30], Yang et al. [29] and Holman [40], $\mathrm{h}_{\text {Free }}$ can be calculated by:

$$
\mathrm{h}_{\text {Free }}=1.31 \sqrt[3]{\mathrm{T}_{\text {module }}-\mathrm{T}_{\mathrm{amb}}} .
$$

When analyzing $h_{\text {Force, }}$ we encounter several empirical approaches, since the circumstances are different in each case. According to Jones and Underwood [28] at a wind speed of $1 \mathrm{~m} / \mathrm{s}$, the various values reported are $1.2 \mathrm{~W} /\left(\mathrm{m}^{2} \mathrm{~K}\right)$ [41], $5.8 \mathrm{~W} /\left(\mathrm{m}^{2} \mathrm{~K}\right)$ [42], $9.1 \mathrm{~W} /\left(\mathrm{m}^{2} \mathrm{~K}\right)$ [37], and $9.6 \mathrm{~W} /\left(\mathrm{m}^{2} \mathrm{~K}\right)$ [43]. Tsai and Tsai [30] and Palyvos [44] analyze the relationship in the following way:

$$
\begin{gathered}
\mathrm{h}_{\text {Force }}=5.6212+3.9252 \mathrm{v}_{\text {Wind }}, \text { if } \mathrm{v}_{\text {Wind }}<4.88 \mathrm{~m} / \mathrm{s} \\
\mathrm{h}_{\text {Force }}=\left(3.290 \mathrm{v}_{\text {Wind }}\right) 0.78, \text { if } 4.88 \leq \mathrm{v}_{\text {Wind }}<30.48 \mathrm{~m} / \mathrm{s}
\end{gathered}
$$


According to Yang et al. [29], the relationship should be amended as follows:

$$
\mathrm{h}_{\text {Force }}=\left(0.5 \mathrm{v}_{\text {Wind }}\right) .
$$

Regarding generally-constructed PV modules, Haber and his colleagues [45-49] have determined a number of overall convection coefficients, depending on wind speed and wind direction, and different installation modes. In all cases, the overall convection coefficients of the photovoltaic modules were tested for five different wind speeds, in the order of $\mathrm{v}_{\text {Wind }}=\mathrm{m} / \mathrm{s}$, based on the most common wind speeds in Hungary. CFD (computational fluid dynamics) simulations were validated by wind tunnel measurements, where the coefficients of pressure factors showed the simulation efficiency or reliability. The overall convection coefficient values are shown in Table 1. We think these data are the most reliable because of the many years of complex investigations; on the other hand, $\mathrm{h}_{\mathrm{conv}}$ data in other literature are not properly detailed, so the accuracy of the theoretical calculations can be uncertain. Therefore, these values were applied for these calculations.

Table 1. Overall convection coefficient values in different installation characteristics of PV modules.

\begin{tabular}{clcc}
\hline PV Module Installation Characteristics & Context & Wind Direction & Ref. \\
\hline \multirow{2}{*}{ PV modules installed on facades } & $\begin{array}{l}\mathrm{h}_{\text {conv }}=3.26+1.75 \mathrm{v}_{\text {Wind }} \\
\mathrm{h}_{\text {conv }}=2.46+0.96 \mathrm{v}_{\text {Wind }}\end{array}$ & $\begin{array}{l}\text { north } \\
\text { south }\end{array}$ & {$[48,49]$} \\
\hline \multirow{2}{*}{ PV modules installed on angled roofs } & $\begin{array}{l}\mathrm{h}_{\text {conv }}=2.93+1.85 \mathrm{v}_{\text {Wind }} \\
\mathrm{h}_{\text {conv }}=2.93+3.62 \mathrm{v}_{\text {Wind }}\end{array}$ & $\begin{array}{l}\text { north } \\
\text { south }\end{array}$ & {$[46,47,49]$} \\
\hline \multirow{2}{*}{ PV modules installed on flat roofs } & $\begin{array}{l}\mathrm{h}_{\text {conv }}=2.90+2.3 \mathrm{v}_{\text {Wind }} \\
\mathrm{h}_{\text {conv }}=2.90+2.17 \mathrm{v}_{\text {Wind }}\end{array}$ & $\begin{array}{l}\text { north } \\
\text { south }\end{array}$ & {$[49]$} \\
\hline Free standing PV modules & $\begin{array}{l}\mathrm{h}_{\text {conv }}=2.90+4.19 \mathrm{v}_{\text {Wind }} \\
\mathrm{h}_{\text {conv }}=2.90+3.13 \mathrm{v}_{\text {Wind }}\end{array}$ & $\begin{array}{l}\text { north } \\
\text { south }\end{array}$ & {$[45,49]$} \\
\hline All installation modes & $\mathrm{h}_{\text {conv }}=2.92+3.26 \mathrm{v}_{\text {Wind }}$ & cross-wind & {$[49]$} \\
\hline
\end{tabular}

This study deals with freestanding, south-facing photovoltaic modules. The contours of the velocity magnitudes and velocity vectors colored according to velocity magnitudes experienced in this installation are shown in Figure 1. The Figure show the contours of the velocity magnitude near the modules. It can be seen (Figure 1) that on the front side of the first module (the first to face the wind direction), at $3 \mathrm{~m} \mathrm{~s}^{-1}$ wind inflow rate, the flow velocity is very low $\left(>0.45 \mathrm{~m} \mathrm{~s}^{-1}\right)$. This leads to a lower heat transfer coefficient, compared to the other two modules where the flow is higher at the front surface [45].

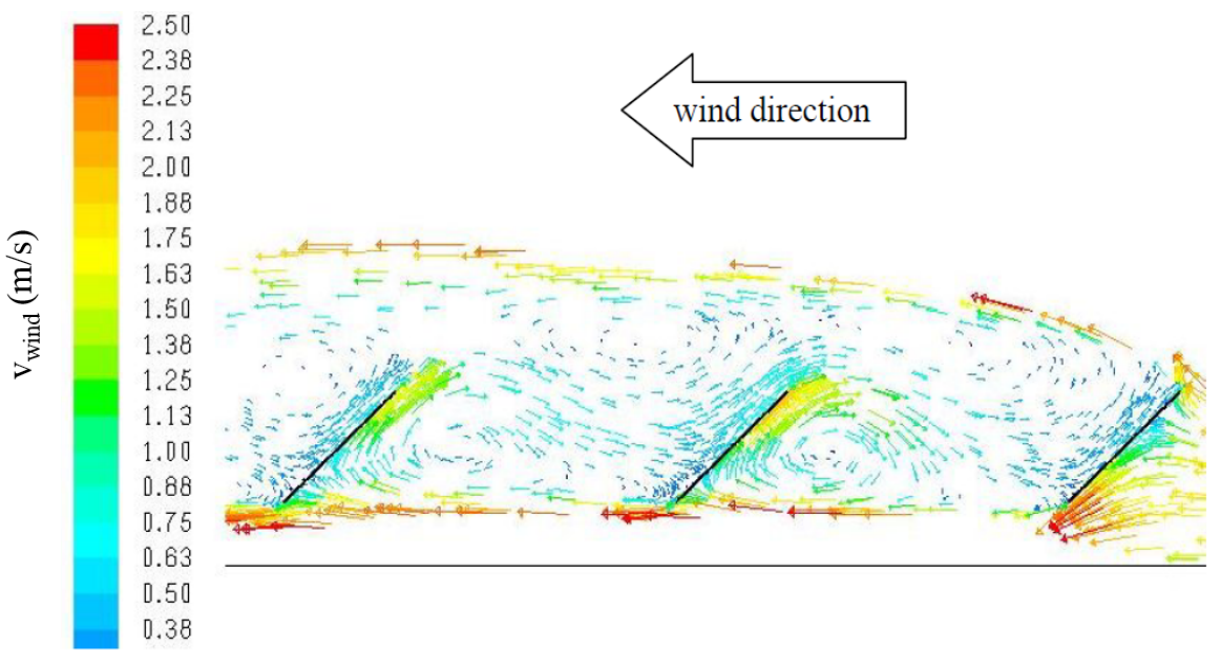

Figure 1. Velocity vectors colored by velocity magnitude at $3 \mathrm{~m} \mathrm{~s}^{-1}$ from north. 
There are various state-of-the-art methods for the optimization of performance [50-55] and for the estimation of energy system properties [56-58]. However, most of them are not suitable for solar energetic systems. A powerful technique for nonlinear fitting is machine learning, which is able to support accurately the acquisition of the values of coefficients of thermal performance when certain easily-measured independent variables are known. Machine learning techniques with appropriate algorithms based on a large database can perform precise predictions and learn from the numerical correlations hidden in the dataset via a nonlinear fitting process. With such a technique, it is not necessary to establish the exact physical model for each coefficient of thermal performance, and a precise prediction can be acquired directly with a well-developed predictive model [59].

Many recent studies have shown that compared with physical or empirical models, machine learning could be a better model to help to reproduce and predict precise thermal properties, based on experimentally-measured databases. The machine learning approaches need, however, for each system and location, a new training set. One machine learning technique set up for one location may not perform appropriately for another location. Physical models may, on the contrary, be used for any location. This work focuses primarily on physical-based model and on the physical description of the heat transfer.

\subsection{System Description}

The thermal properties of crystalline and amorphous silicon photovoltaic modules were studied in our work, and the remaining energy $\left(\mathrm{Q}_{\mathrm{rem}, \mathrm{E}}\right)$ and energy production $\left(\mathrm{W}_{\mathrm{pv}}\right)$ of the modules was tested in ideal and actual summer weather conditions.

The data collection for the research work was carried out in Hungary, in the town of Keszthely (Hungary) (latitude: $46.76750^{\circ}$, longitude: $17.26609^{\circ}$ ) on eight different days: 7 July 2016, 19 July 2016, 22 July 2016, 7 August 2016, 8 August 2016, 6 July 2017, 10 July 2017, and 18 July 2017. The study was performed with a dual-axis tracking system using amorphous silicon, polycrystalline, and monocrystalline photovoltaic technology, under real meteorological conditions, at the same measuring point. In Hungary, in the case of south-facing systems, the ideal yearly angle of inclination is $35^{\circ}$ [60], so this setting is tested in this work (Table 2, Figure 2).

Table 2. Electrical and mechanical characteristics of the solar modules examined.

\begin{tabular}{cccc}
\hline Characteristics & $\begin{array}{c}\text { Polycrystalline Solar } \\
\text { Module }\end{array}$ & $\begin{array}{c}\text { Monocrystalline Solar } \\
\text { Module }\end{array}$ & $\begin{array}{c}\text { Amorphous Silicon } \\
\text { Solar Module }\end{array}$ \\
\hline Manufacturer $/$ Distributer & Energiesolaire100 & Prevent GmbH & Kaneka \\
Country of origin & Italy & Germany & Japan \\
Model & SL50TU-18P & SM636-50 & 5050 \\
Nominal performance $\left(\mathrm{P}_{\mathrm{m}}\right)(\mathrm{W})$ & 50 & 50 & 50 \\
Performance tolerance $(\%)$ & $\pm 3 \%$ & $\pm 3 \%$ & $\pm 10 \%$ \\
MPP current $\left(\mathrm{I}_{\mathrm{mp}}\right)(\mathrm{A})$ & 2.62 & 2.8 & 0.75 \\
MPP voltage $\left(\mathrm{V}_{\mathrm{mp}}\right)(\mathrm{V})$ & 19.12 & 18.18 & 67 \\
Short circuit current $\left(\mathrm{I}_{\mathrm{sc}}\right)(\mathrm{A})$ & 2.80 & 3.08 & 1.19 \\
Open circuit voltage $\left(\mathrm{V}_{\text {oc }}\right)(\mathrm{V})$ & 22.68 & 23.17 & 91.8 \\
Module size $(\mathrm{mm}):$ & $545 \times 668 \times 28$ & $510 \times 680 \times 35$ & $960 \times 990 \times 40$ \\
(width $\times$ height $\times$ depth) & & & \\
\hline
\end{tabular}




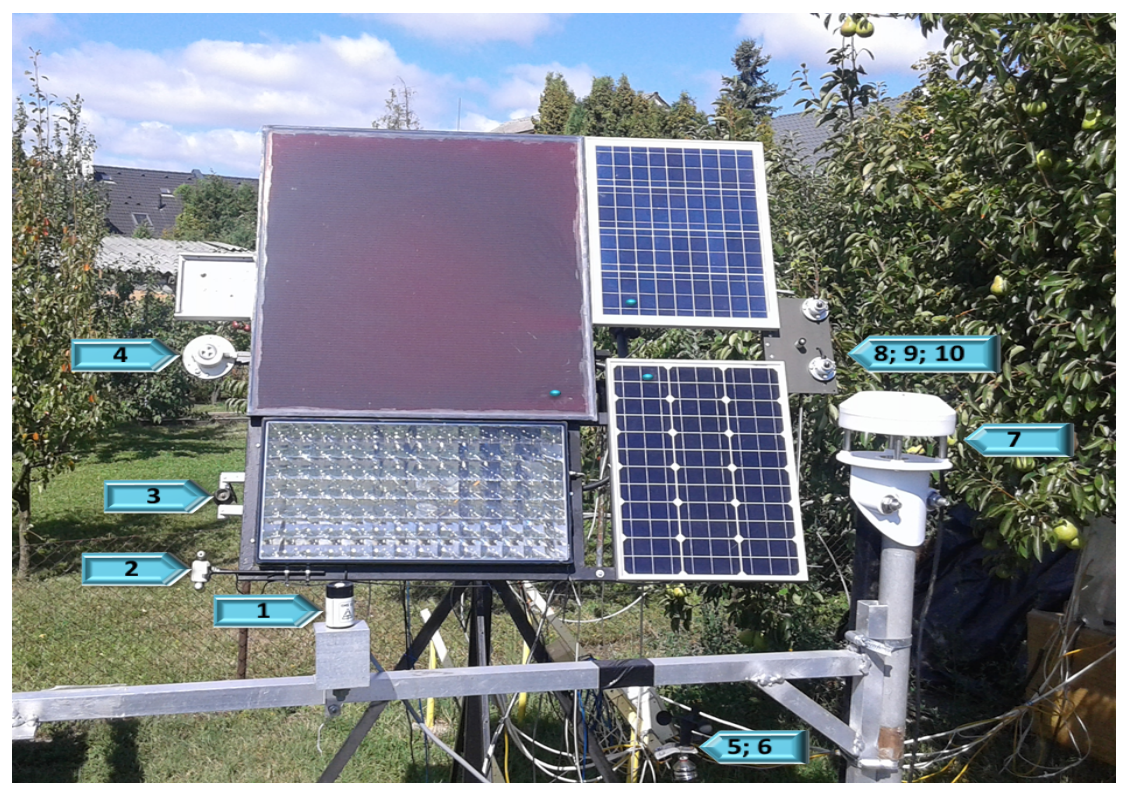

Figure 2. The measuring station of the sun-tracking system used for the present study. * (upper left, amorphous silicon; lower left, CPV; upper right, polycrystalline; lower right monocrystalline technology) (1, 10, EMS 11 Silicon photovoltaic detector; 2, SN-500 four-component net radiometer; 3, photosensors; 4, Eppley Black and White pyranometer; 5, JL-FS2 aluminium device with 3 spoons; 6, HYTE-ANA-1735 humidity content of air meter; 7, DS-2 Sonic anemometer; 8, 9, Hukseflux LP02 pyranometer.

In the course of the experiments, the collection meteorological and PV modules data were carried out using four measuring data acquisition systems (Figures 3 and 4):

- One PicoLog 1012 data acquisition system (Pico Technology, St Neots, UK);

- One PicoLog 1216 data acquisition system; (Pico Technology, St Neots, UK);

- One CR1000 measurement and control datalogger (Campbell Scientific, Inc., Logan, UT, USA);

- One GB HOBO four-channel analog data logger (Onset Computer Corporation, Bourne, MA, USA).

The Voltcraft VC607 (Conrad Electronic SE, Wernberg-Köblitz, Germany) (independent measuring device) professional multimeter was used to calibrate the voltages and currents (measuring point A, Figure 3), and was checked before the measurements with an LT1021voltage reference (Linear Technology Corporation, Milpitas, CA, USA, $10.000 \mathrm{~V} \pm 5 \mathrm{mV}$ ).

Pt 100 sensors (Conrad Electronic SE, Wernberg-Köblitz, Germany) were used to measure the photovoltaic module and air temperature. A digital LM 35 (B+B Thermo-Technik $\mathrm{GmbH}$, Donaueschingen, Germany)-based precision thermometer (independent measuring device) was used to calibrate the entire measuring circuit (measuring point A, Figure 3), and the LM 35 precision thermometer has a $+10.0 \mathrm{mV} /{ }^{\circ} \mathrm{C}$ change in signal leading to $0.1 \mathrm{~V}$ at $1^{\circ} \mathrm{C}$ and $1 \mathrm{~V}$ at $100{ }^{\circ} \mathrm{C}$. Its accuracy is stated as $\pm 0.25^{\circ} \mathrm{C}$ at room temperature and $\pm 0.75{ }^{\circ} \mathrm{C}$ between $-55^{\circ} \mathrm{C}$ and $+150{ }^{\circ} \mathrm{C}$. The temperature of photovoltaic modules was measured at a point on the back part (marked with a blue dot, Figure 2). Air temperature was also determined by a DS-2 sonic anemometer (Figure 4).

The humidity of the air was measured by a HYTE-ANA-1735 meter (B+B Thermo-Technik GmbH, Donaueschingen, Germany, $\pm 3 \%$ accuracy), while the wind velocity was determined by a JL-FS2, three-channel aluminum meter (Alex NLD, Tiberias, Israel, $\pm 3 \%$ accuracy) and a sonic anemometer DS-2. The wind direction was also determined by the DS-2 sonic anemometer (METER Group, Inc. München, Germany, $\pm 3 \%$ accuracy). 
The incoming solar irradiance was measured with an Eppley Black and White Model 4-48 pyranometer (The Eppley Laboratory, Inc., Newport, RI, USA, $\pm 3-5 \%$ uncertainty), an EMS 11 silicon photovoltaic detector (Energy XPRT, Brno, Czech Republic, $\pm 7-10 \%$ uncertainty), two Hukseflux LP02 pyranometers (Hukseflux Thermal Sensors B.V., Delft, The Netherlands, $\pm 1-3 \%$ uncertainty), and the global horizontal irradiation by an EMS 11 Silicon photovoltaic detector (Figures 2-4).

A SN-500 four-component net radiometer (Apogee Instruments, Inc., Logan, UT, USA, $\pm 5 \%$ uncertainty), an upward- and a downward-looking pyranometer, and an upward- and a downward-looking pyrgeometer provide separate measurements of the four components of net radiation (Figures $2-4$ ).

For the solar modules, the maximum power point was maintained using true maximum point seeking (TMPS), operating on an oscillating principle. By keeping the multiplier of the voltage and current power (i.e., of the maximum performance at that moment) at the highest value, the solar modules operated at the maximum power point. With the help of these devices it is possible to manually check the maximum power point of the PV modules, thus allowing the correct measurement accuracy (Figure 3).

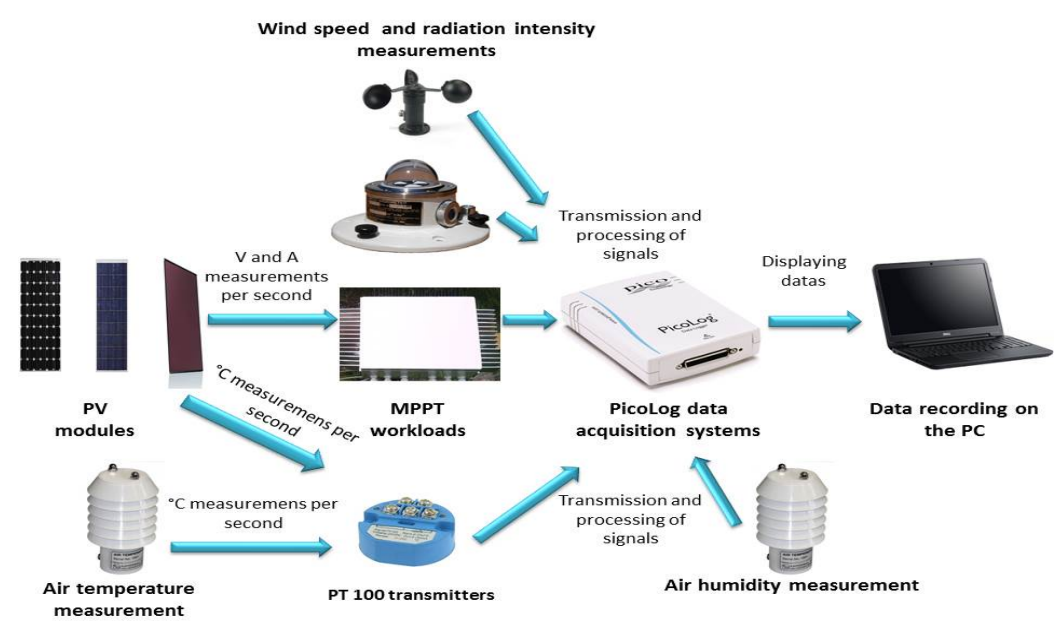

Figure 3. Schematic illustration of solar module measuring station 'A'.

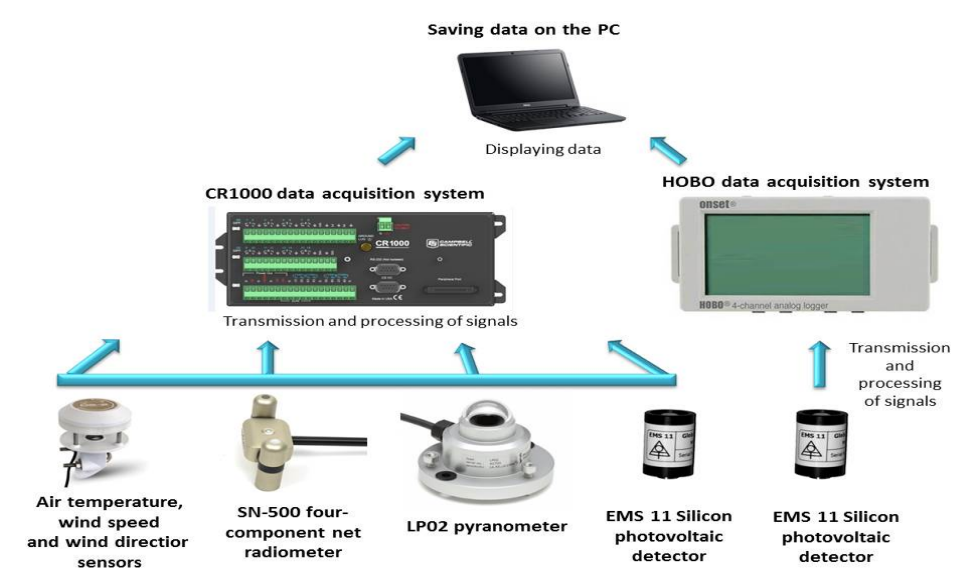

Figure 4. Schematic illustration of solar module measuring station 'B'.

During our investigations in 2016, only the measuring station 'A' (Figure 3) was used. In 2017, measuring stations ' $A$ ' and ' $B$ ' were used at the same places and times (Figures 3 and 4).

To determine the emission value of photovoltaic modules, a FLIR E60BX infrared camera (FLIR Commercial Systems Inc., Nashua, NH, USA) was used. For modules installed outdoor, reflections of radiation coming from the surroundings may lead to problems for the determination of 
the true emission value. For this reason, the experiment control was performed in a closed space with the same photovoltaic modules using the FLIR E60BX infrared camera with a manual Voltcraft K204 datalogger coupled with a k-type TP-K-02 thermometer (Conrad Electronic SE, Wernberg-Köblitz, Germany tolerance, $\pm 0.75 \%$ ). To analyze, evaluate, and manage the data, PicoScope (Pico Technology, St Neots, UK), Microsoft Excel (Microsoft Corporation, Redmond, WA, USA) and SPSS Statistics 24 software (SPSS, Chicago, IL, USA).

For each measurement case continuous second (station ' $\mathrm{A}$ ') and average minute (station ' $\mathrm{B}$ ') measurements were performed. The station ' $\mathrm{A}$ ' results were averaged for every minute.

Since the systematic mistakes do not increase the deviation of the measurements, it is difficult to detect them, but the given measuring accuracy and calibration (which should be independent of the measuring system) of the measuring devices can help to solve this problem.

\section{Results and Discussion}

\subsection{Recommended Thermal Relationship for South-Facing Photovoltaic Modules}

Several methods have been observed for thermodynamic processes related to PV modules (see the 'Thermal Dynamics for Photovoltaic Modules' section). On the measurement site in Keszthely (Hungary), two shady periods occurred in the early morning and in the late afternoon, which could have distorted the results. Therefore, for the net long-wave radiation, continuous second and average minute measurements were performed from 09:00 to 17:40 on 6 July 2017, 10 July 2017, and 18 July 2017 with the SN-500 four-component net radiometer verifying the correctness of the theoretical formulas. The proposed empirical method (Table 3) of Jones and Underwood [28] may be used regarding the net long-wave radiation at the top of the module surface $\left(\mathrm{Q}_{\mathrm{lw}, \mathrm{up}, \mathrm{E}}\right)$, but no solution is suggested for the calculation of the net long wave radiation at the bottom of the module surface $\left(\mathrm{Q}_{\mathrm{lw}, \mathrm{down}, \mathrm{E}}\right)$. Yang et al.'s [29] approach to the PV absorptivity value $(\alpha)$ renders the results inaccurate, but ignoring this and the $\frac{\left(1+\cos \beta_{\text {surface }}\right)}{2}, \frac{\left(1-\cos \beta_{\text {surface }}\right)}{2}$ relationships, we obtain the same result. Therefore, Yang et al.'s [29] correlation can be compared to the approach we propose.

The overall convection coefficient values recorded by Haber and Farkas [45] and Haber [49] were used in the case of south-facing free-standing PV modules, with respect to the rate of net energy exchange at the module by convection $\left(\mathrm{Q}_{\mathrm{conv}, \mathrm{E}}\right)$. These data (Table 1$)$ seemed to be the most reliable since they are based on many years of complex investigations. These values developed for free standing PV modules were used for the present calculations. The proposed complete empirical equations with the recommended emitted long-wave radiation and the convective heat transfer on the PV module, based on the wind direction, are shown in the Table 3 below.

Table 3. Recommended approach to thermal calculations for ground-installed, south-facing PV modules.

\begin{tabular}{|c|c|}
\hline Description & Context \\
\hline $\begin{array}{l}\text { Remaining heat on PV } \\
\text { module }\left(Q_{\text {rem }},[\mathrm{W}]\right)\end{array}$ & $\mathrm{Q}_{\mathrm{rem}}=\mathrm{Q}_{\mathrm{sw}}-\mathrm{Q}_{\mathrm{lw}, \text { total }}-\mathrm{Q}_{\mathrm{conv}}-\mathrm{P}_{\mathrm{pv}}$ \\
\hline $\begin{array}{l}\text { Effective irradiation on } \mathrm{PV} \\
\text { module }\left(\mathrm{Q}_{\mathrm{sw}},[\mathrm{W}]\right)\end{array}$ & $\mathrm{Q}_{\mathrm{sw}}=\alpha \mathrm{G} \mathrm{A}_{\mathrm{PV}}$ \\
\hline \multirow{3}{*}{$\begin{array}{l}\text { * Emitted long-wave } \\
\text { radiation }\left(\mathrm{Q}_{\mathrm{lw}},[\mathrm{W}]\right)\end{array}$} & $\begin{array}{c}\mathbf{Q}_{\text {lw, up }}= \\
\mathrm{A}_{\mathrm{PV}} \sigma\left(\frac{\left(1+\cos \beta_{\text {surface }}\right)}{2} \varepsilon_{\text {sky }} \mathrm{T}_{\text {sky }}^{4}+\frac{\left(1-\cos \beta_{\text {surface }}\right)}{2} \varepsilon_{\text {ground }} \mathrm{T}_{\text {ground }}^{4}-\varepsilon_{\text {module }} \mathrm{T}_{\text {module }}^{4}\right)\end{array}$ \\
\hline & $\begin{array}{c}\mathbf{Q}_{\text {lw, down }}= \\
\mathrm{A}_{\mathrm{PV}} \sigma\left(\frac{\left(1+\cos \beta_{\text {surface }}\right)}{2} \varepsilon_{\text {ground }} \mathrm{T}_{\text {ground }}^{4}+\frac{\left(1-\cos \beta_{\text {surface }}\right)}{2} \varepsilon_{\text {sky }} \mathrm{T}_{\text {sky }}^{4}-\varepsilon_{\text {module }} \mathrm{T}_{\text {module }}^{4}\right)\end{array}$ \\
\hline & $\begin{array}{c}\mathbf{Q}_{\text {lw, total }}=\mathbf{Q}_{\text {lw, up }}+\mathbf{Q}_{1 \mathbf{w}, \text { down }} \\
\mathrm{A}_{\mathrm{PV}} \sigma\left(\frac{\left(1+\cos \beta_{\text {surface }}\right)}{2} \varepsilon_{\text {sky }} \mathrm{T}_{\text {sky }}^{4}+\frac{\left(1-\cos \beta_{\text {surface }}\right)}{2} \varepsilon_{\text {ground }} \mathrm{T}_{\text {ground }}^{4}+\right. \\
\left.\frac{\left(1+\cos \beta_{\text {surface }}\right)}{2} \varepsilon_{\text {ground }} \mathrm{T}_{\text {ground }}^{4}+\frac{\left(1-\cos \beta_{\text {surface }}\right)}{2} \varepsilon_{\text {sky }} \mathrm{T}_{\text {sky }}^{4}-2 \varepsilon_{\text {module }} \mathrm{T}_{\text {module }}^{4}\right)\end{array}$ \\
\hline
\end{tabular}


Table 3. Cont.

\begin{tabular}{ccc}
\hline Description & \multicolumn{2}{c}{ Context } \\
\hline $\begin{array}{c}\text { Convective heat transfer on } \\
\text { PV module }\left(\mathrm{Q}_{\text {conv }},[\mathrm{W}]\right)\end{array}$ & \multicolumn{1}{c}{$\mathrm{Q}_{\text {conv }}=\mathrm{A}_{\mathrm{PV}} \mathrm{h}_{\text {conv }}\left(\mathrm{T}_{\text {module }}-\mathrm{T}_{\mathrm{amb}}\right)$} \\
\hline \multirow{2}{*}{$\begin{array}{c}\text { Overall convective heat } \\
\text { transfer }\left(\mathrm{W} /\left(\mathrm{m}^{2} \mathrm{~K}\right)\right)\end{array}$} & $\mathrm{h}_{\text {conv }}=2.90+4.188 \mathrm{v}_{\text {Wind }}$, & north wind direction \\
\cline { 2 - 3 } & $\mathrm{h}_{\text {conv }}=2.90+3.128 \mathrm{v}_{\text {Wind }}$ & south wind direction \\
\cline { 2 - 3 } & $\mathrm{h}_{\text {conv }}=2.92+3.26 \mathrm{v}_{\text {Wind }}$, & cross-wind \\
\hline
\end{tabular}

* Authors' own results based on SN-500 four-component net radiometer.

\subsection{Experimental Results and Discussion}

Thermal processes of PV Modules were carried out during the eight days. Continuous second and average minute measurements were performed from 09:00 to 17:40 since, at this time, the environmental and experimental conditions were the most favorable for the test. This represents a total of 31, 200 (second-based) and 520 (minute-based) measurements/measurement days. During the examinations in 2016, only measuring station 'A' (Figure 3) was used while, in 2017, both (Figures 3 and 4) measuring stations ' $\mathrm{A}$ ' and ' $\mathrm{B}$ ' were used at the same places and times. Instead of using Joules, the use of Ws notation was preferred because the thermal processes of PV modules were examined in Ws or Wh in the studies we consulted.

Figures 5 and 6 illustrate the real global tilted irradiation $\left(35^{\circ}\right)$, the temperature characteristics, and the real energetic characteristics of the $\mathrm{m}-\mathrm{Si}, \mathrm{p}-\mathrm{Si}$, and a-Si modules during daylight hours on 18 July 2017, as shown below. These figures are provided to facilitate an understanding of our calculations and measurements, i.e., heat components and the transformation of the net short-wave radiation in the other heat components.

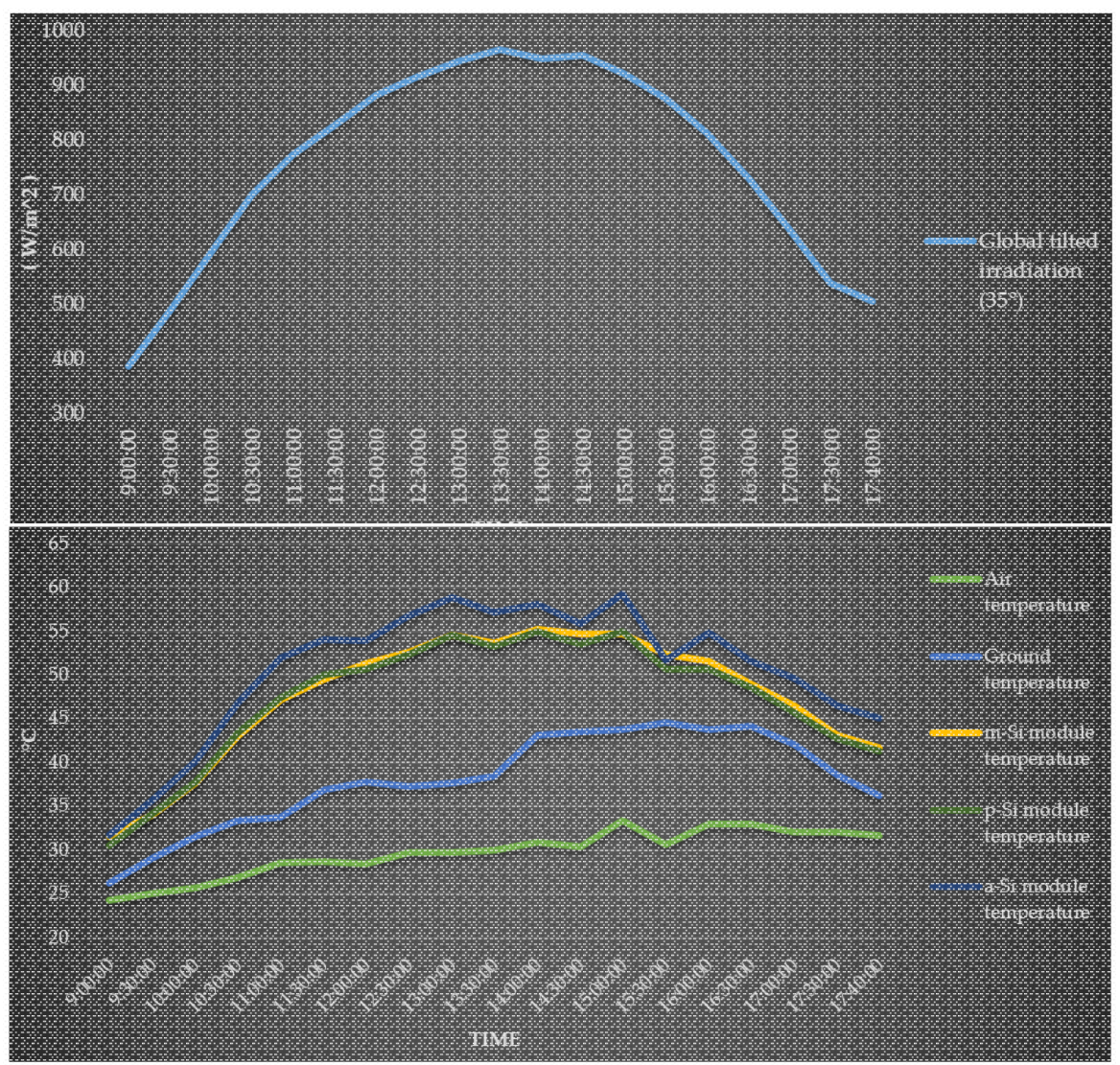

Figure 5. lllustrating the real global tilted irradiation $\left(35^{\circ}\right)$ and the temperature characteristics of the m-Si, p-Si, and a-Si modules from 09:00 to 17:40 on 18 July 2017. 

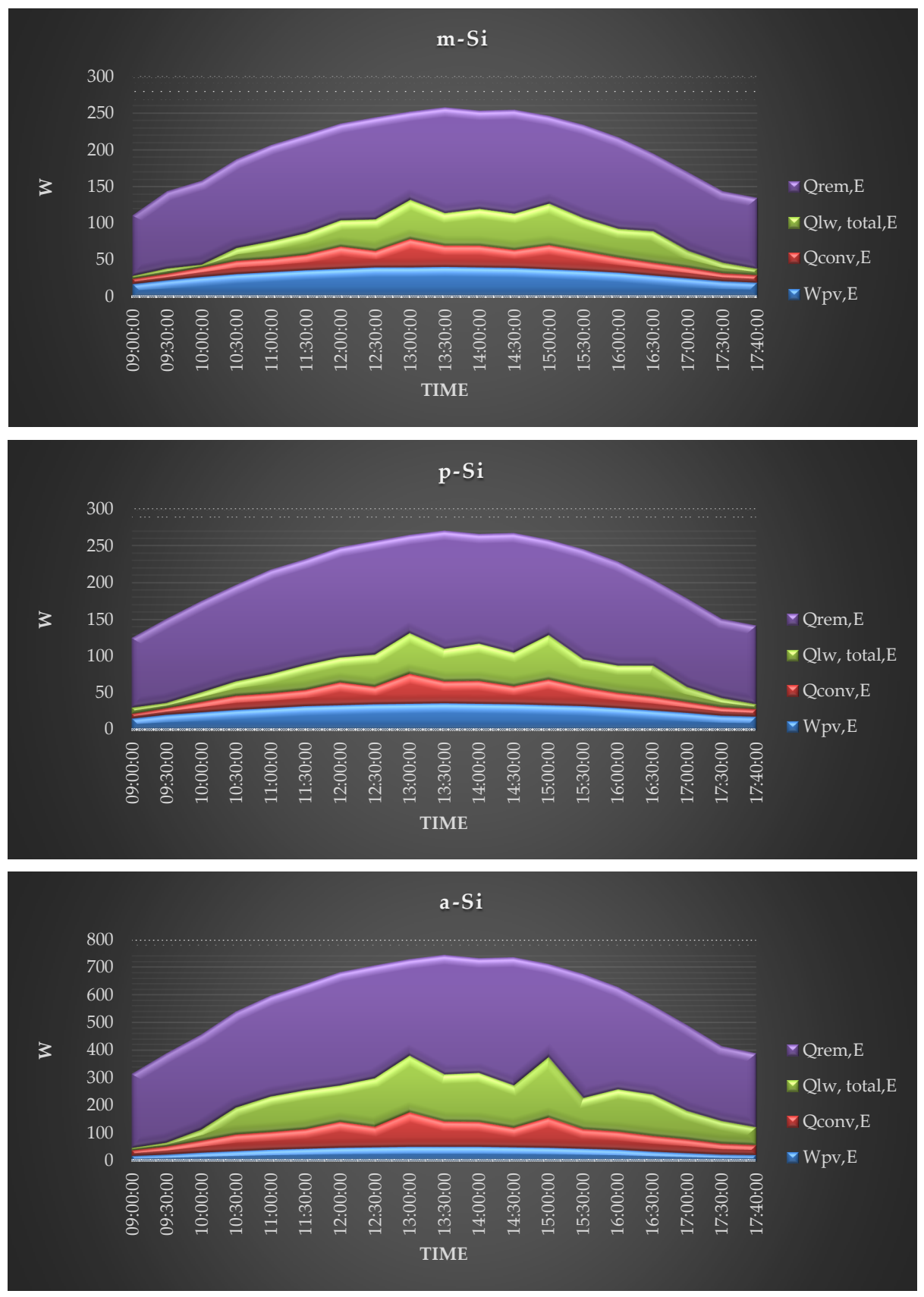

Figure 6. lllustrating the real energetic characteristics of the $\mathrm{m}-\mathrm{Si}, \mathrm{p}-\mathrm{Si}$, and a-Si modules from 09:00 to 17:40 on 18 July 2017.

For the calculations of the heat transfer and components of the PV module $\left(\mathrm{Q}_{\mathrm{rem}, \mathrm{E}}=\mathrm{Q}_{\mathrm{sw}, \mathrm{E}}-\right.$ $\mathrm{Q}_{\mathrm{lw}, \text { total,E}}-\mathrm{Q}_{\mathrm{conv}, \mathrm{E}}-\mathrm{W}_{\mathrm{pv}}$ ), simulations as a function of time were performed using algorithms for south-facing PV modules mentioned above. The use of $\mathrm{Q}_{\mathrm{rem}, \mathrm{E}}$ is more appropriate under real weather conditions, as an accurate determination of $\dot{\mathrm{T}}_{\text {module }}$ is not possible due to the constant changes in environmental conditions.

The $\mathrm{T}_{\mathrm{sky}}=\mathrm{T}_{\mathrm{amb}}$ formula was taken into account since during the heat exchanges the surrounding space of the PV module is important [39].

The precise determination of the emission values of the PV modules was achieved in a closed space using photovoltaic modules of the same type. For this experiment, a handheld Voltcraft K204 datalogger and a k-type TP-K-02 thermometer, as well as a FLIR E60BX infrared camera were used. 
An emission coefficient of 0.9 was obtained for all three solar module technologies. This value is confirmed by Jones and Underwood [28], Tsai and Tsai [30], and Acciani et al. [38].

The absorption value was 0.77 for crystalline PV modules [28], and 0.81 for amorphous silicon photovoltaic modules [61].

For thermal studies, the relationship between the average remaining heat energy-temperature change and the relative standard deviation during the warming period is determined from the daily data. The relative standard deviation $(\mathrm{CV} \%)$ was applied because the deviation only shows variability, while the average and the spread of data are also important factors. According to Szúcs, a relative standard deviation between 0 and $10 \%$ shows homogeneous conditions, the relative standard deviation between $10.1 \%$ and $20 \%$ shows a medium variability, and the standard deviation between $20.1 \%$ and $30 \%$ shows a strong variability. Values above $30.1 \%$ show strongly heterogeneous conditions [62]. In our study, a medium variation may be considered as acceptable due to the constant changes of the environmental conditions.

It is only possible to compare Yang et al.'s [29] correlation to the present modelling approach because of the similarity of the simulated components. For this reason, only a comparison of our model with Yang et al.'s [29] is shown in the following section. The work was tailored to PV measurements. In 2016, we were not able to measure the SN-500 four-component net radiometer. For this reason, we first compared the average deviation over eight days between our and Yang et al.'s [29] models. The results were calculated per second. By means of experiments, the average energy needs to set up a temperature change of $1^{\circ} \mathrm{C}$ in the PV modules for photovoltaic modules with optimum placement, orientation and average power at the typical air temperature range of $23-40^{\circ} \mathrm{C}$ and module temperature range of $29-64{ }^{\circ} \mathrm{C}$ were determined by measurements (Figure 7).

The average deviations of our model compared to Yang et al.'s [29] formula were as follows:

- m-Si modules: $-13 \%$,

- p-Si modules: $-4.2 \%$,

- a-Si modules: $-12.2 \%$.

The average $\mathrm{CV} \%$ deviations of the two models based on eight days were homogeneous:

- m-Si modules, our model: 3.1\%;

- $\quad \mathrm{m}-\mathrm{Si}$ modules, Yang et al.'s [29]: 4.1\%;

- $\quad$-Si modules, our model: $6.7 \%$;

- $\quad$-Si modules, Yang et al.'s [29]: 6.3\%;

- $\quad$ a-Si modules, our model: $4.9 \%$; and

- a-Si modules, Yang et al.'s [29]: 6.9\%.

For the measurements in 2017, SN-500 four-component net radiometer were additionally used, so the accuracy of the models could be checked. The data were measured on three days: 6 July 2017, 10 July 2017 and 18 July 2017 from 09:00 to 17:40. The results were averaged for every minute. The relative standard deviation showed homogeneity in all three cases (measured, our model calculation and Yang et al.'s model solution) (Table 4).

The average deviations from the measured data were the following: (Table 4):

- for monocrystalline modules (m-Si modules), our model: $-4.2 \%$;

- for monocrystalline modules (m-Si modules), Yang et al.'s [29] model: $-12.5 \%$;

- for polycrystalline modules (p-Si modules), our model: $-3.7 \%$;

- for polycrystalline modules (p-Si modules), Yang et al.'s [29] model: $-11.1 \%$;

- for amorphous silicon solar modules (a-Si modules), our model: $-4.2 \%$;

- for amorphous silicon solar modules (a-Si modules), Yang et al.'s [29] model: $-15.3 \%$. 


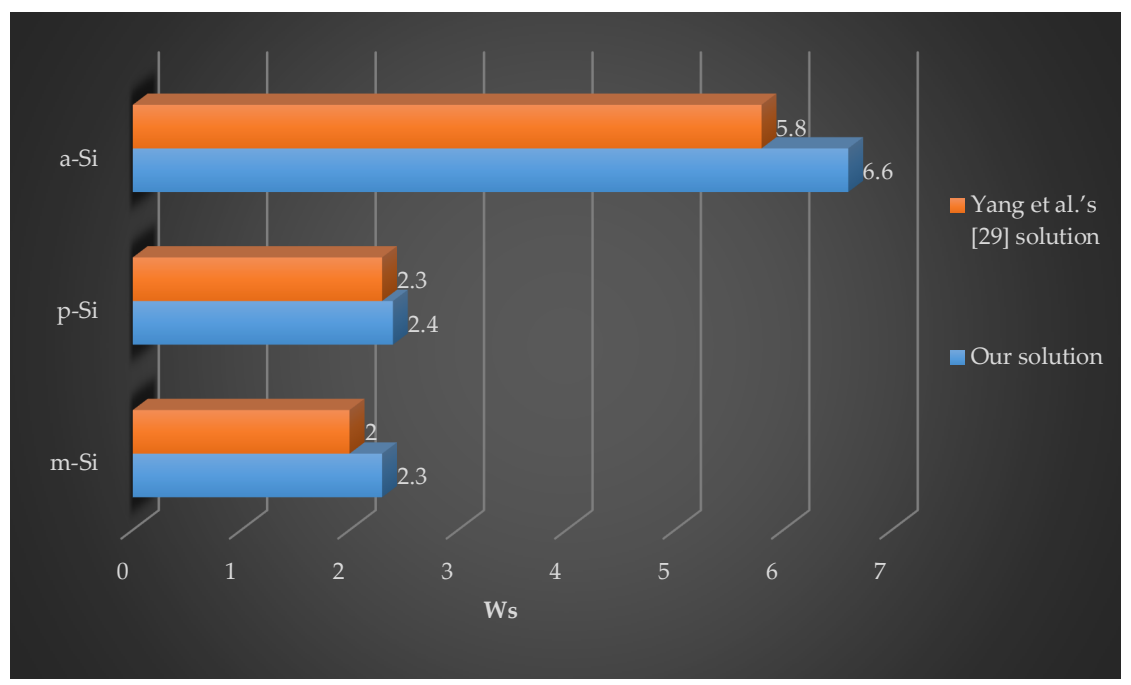

Figure 7. The average of results of the two models over eight days (calculated heat energy required for a $1{ }^{\circ} \mathrm{C}$ change in temperature of the photovoltaic modules).

Table 4. The comparison of Yang et al.'s [29] and our model with the measured heat energy required for a $1^{\circ} \mathrm{C}$ change in temperature of the photovoltaic module.

\begin{tabular}{ccccccccccc}
\hline & \multicolumn{3}{c}{ m-Si (Ws) } & \multicolumn{3}{c}{ p-Si (Ws) } & \multicolumn{3}{c}{ a-Si (Ws) } \\
\cline { 2 - 9 } Description & Ws & $\begin{array}{c}\text { Relation } \\
\mathbf{( \% )}\end{array}$ & CV\% & Ws & $\begin{array}{c}\text { Relation } \\
\mathbf{( \% )}\end{array}$ & CV\% & Ws & $\begin{array}{c}\text { Relation } \\
\mathbf{( \% )}\end{array}$ & CV\% \\
\hline $\begin{array}{c}\text { Three-day average, measured (Ws) } \\
\text { Three-day average, our model } \\
\text { calculation (Ws) }\end{array}$ & 2.4 & 100 & 2 & 2.7 & 100 & 1.9 & 7.2 & 100 & 0 \\
$\begin{array}{c}\text { Three-day average, Yang et al.'s [29] } \\
\text { model solution (Ws) }\end{array}$ & 2.3 & 95.8 & 0 & 2.6 & 96.3 & 0 & 6.9 & 95.8 & 3.4 \\
\hline
\end{tabular}

The heat exchange values of the crystalline and amorphous silicon PV modules are related to the differences in the surface, type and weight of the modules.

During the analysis of the heat transfer of PV modules during the period from 09:00 to 17:40 on 6 July 2017, 10 July 2017, and 18 July 2017, the three-day average, the daily relationships of the remaining heat energy $\left(Q_{\text {rem, } E}\right)$, the electricity energy output by the $P V$ module $\left(\mathrm{W}_{\mathrm{pv}}\right)$, the total net long-wave radiation at the module surface $\left(\mathrm{Q}_{\mathrm{lw}, \text { total,E}}\right)$ and the rate of net energy exchange at module by convection $\left(\mathrm{Q}_{\mathrm{conv}, \mathrm{E}}\right)$ were performed for all three photovoltaic technologies, based on measurements and models. During the measurement periods, the main part of incident solar energy was converted in heat energy remaining in the PV modules $\left(\mathrm{Q}_{\mathrm{rem}, \mathrm{E}}\right)$, thus increasing the temperature of the modules. The electricity production illustrates the efficiency of the photovoltaic modules very well. Measured data correspond to $100 \%$ because this is the reality; in turn, the two models were compared to the measured values. The combined values of the total net long-wave radiation at the module surface and the rate of net energy exchange at the module by convection are $27 \%$ for the $\mathrm{m}$-Si module, $25 \%$ for the p-Si module, and 31\% for the a-Si module based on real data. During the measurement period, the $\mathrm{m}$-Si module transformed $16 \%$ of the incoming total energy into electricity, the p-Si module $13 \%$, and the a-Si module 7\%. The real total net long-wave radiation at the module surface data differ from our calculations by 1-2\%, while Yang et al.'s [29] model shows a 3\% deviation. The main deviation was $10-12 \%$ of net energy exchange at the module by convection, so it is essential to choose the right value based on the different installation modes. The determination uncertainty of convective heat transfer leads to uncertainties in the simulated $Q_{\text {rem }}$ value. This shows the importance of an accurate determination of the convective energy component to obtain a correct description of PV module $\left(\mathrm{Q}_{\text {conv }}\right)$ heat transfer (Table 5). In Figure 8 the real and modelled daily energy distribution for $\mathrm{m}-\mathrm{Si}$ 
technology is illustrated for 6 July 2017. This illustration-which facilitates understanding of daily energy distribution-shows the daily energy distribution of the two models and our measured data.

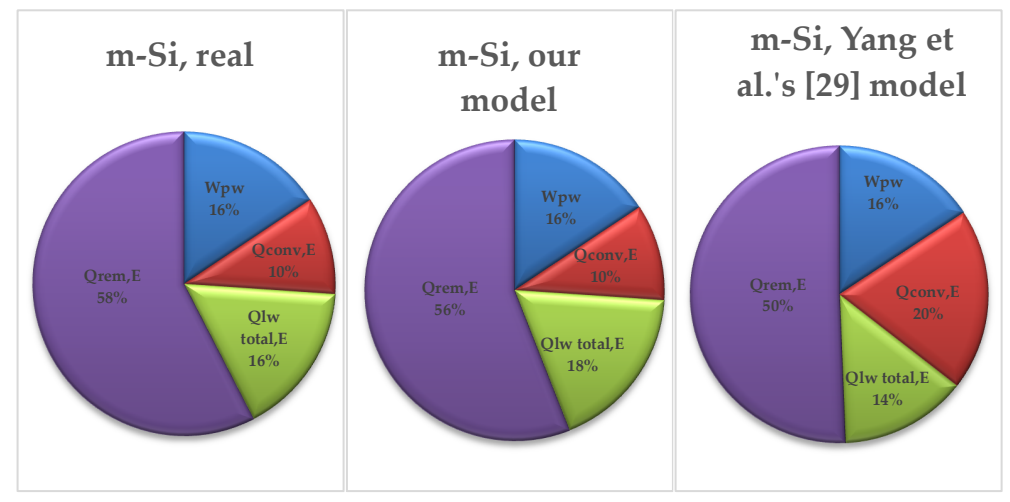

Figure 8. Daily energy distribution for the monocrystalline (m-Si) solar module (6 July 2017 09:00-17:40).

Table 5. Daily energy distribution for the monocrystalline (m-Si), polycrystalline (p-Si), and amorphous silicon (a-Si) solar modules (6, 10, and 18 July 2017, 09:00-17:40).

\begin{tabular}{|c|c|c|c|c|c|c|c|c|c|c|c|c|}
\hline \multirow{2}{*}{ Description } & \multicolumn{4}{|c|}{ m-si } & \multicolumn{4}{|c|}{ p-Si } & \multicolumn{4}{|c|}{ a-Si } \\
\hline & $\mathrm{Q}_{\text {rem }}$ & $\mathrm{Q}_{\text {lw,total }}$ & $Q_{\text {conv }}$ & $\mathbf{W}_{\mathrm{pv}}$ & $Q_{\text {rem }}$ & $\mathrm{Q}_{\text {lw,total }}$ & $Q_{\text {conv }}$ & $\mathrm{W}_{\mathrm{pv}}$ & $Q_{\text {rem }}$ & $\mathrm{Q}_{1 \mathrm{w}, \text { total }}$ & $Q_{\text {conv }}$ & $\mathrm{W}_{\mathrm{pv}}$ \\
\hline Three day average, measured (\%) & 58 & 16 & 10 & 16 & 62 & 16 & 9 & 13 & 62 & 21 & 10 & 7 \\
\hline $\begin{array}{l}\text { Three day average, our model } \\
\text { solution }(\%)\end{array}$ & 56 & 18 & 10 & 16 & 61 & 17 & 9 & 13 & 61 & 22 & 10 & 7 \\
\hline $\begin{array}{l}\text { Three day average, Yang et al.' } \\
\text { model solution }(\%)\end{array}$ & 50 & 14 & 20 & 16 & 54 & 14 & 19 & 13 & 54 & 17 & 22 & 7 \\
\hline $\begin{array}{l}\text { Average deviation from our model } \\
\text { calculation }(\%)\end{array}$ & -2 & +2 & 0 & 0 & -1 & +1 & 0 & 0 & -1 & +1 & 0 & 0 \\
\hline $\begin{array}{l}\text { Average deviation from Yang et al.'s } \\
\text { [29] model solution (\%) }\end{array}$ & -8 & -2 & +10 & 0 & -8 & -2 & +10 & 0 & -8 & -4 & +12 & 0 \\
\hline
\end{tabular}

\section{Conclusions}

In the case of photovoltaic cells and photovoltaic modules, the temperature fluctuation due to changes in solar irradiance is an important factor. For crystalline PV modules, a temperature increase of $1{ }^{\circ} \mathrm{C}$ typically results in a $0.5 \%$ reduction in efficiency, while with amorphous silicon photovoltaic modules this figure is, on average, $0.27 \%$.

The thermal processes of the PV modules have been studied by a number of scientific publications, but all test methods differ from one another regardless of the installation method, and so produce different results. As a result of our research, we suggested a new algorithm for the heat transfer model for the calculation of heat transfer of ground-installed, south-facing PV systems. Using these new modelling approaches the net long-wave radiation and the rate of net energy exchange by convection at the module surface can be more accurately calculated than is currently the case in the literature. Under clear-sky conditions, the real measured total net long-wave radiation at the module surface data differ from our calculations by $1-2 \%$, while Yang et al.'s [29] approach shows a $2-4 \%$ deviation. The main deviation for the net energy exchange at the module by convection was $10-12 \%$. This showed that it is essential to choose the right value based on the different installation modes. The overall convection coefficients of the photovoltaic modules were tested with the help of the newest measurements based on the most common wind speeds in Hungary. CFD (computational fluid dynamics) simulations were validated by wind tunnel measurements, where the coefficients of pressure factors showed the simulation efficiency or reliability. In this way a more accurate overall coefficient to be used for the different photovoltaic modules taking into account the methods of installation could be obtained. 
This allows a more accurate determination of the remaining heat energy on the PV module $\left(Q_{\text {rem,E }}\right)$, which is necessary for the complete energy analysis of the PV module. Further, these findings are crucial for establishing comprehensive economic studies involving photovoltaic modules. Our results also allow us to calculate the thermal technology relationships of PV modules mounted on façades, on sloping roofs, and on flat roofs.

Author Contributions: H.Z. conceived, designed, and performed the experiments. G.P. is the corresponding author because he has been responsible for the management of this article, and P.W. has provided the most comprehensive scientific background for the experiment. All authors contributed equally in the analysis of the data and the writing and revision of the manuscript.

Acknowledgments: This work was supported by the Austrian Hungarian Action Foundation [AÖU Project 96ÖU1] and the research was financed by the Higher Education Institutional Excellence Programme of the Ministry of Human Capacities in Hungary, within the framework of the 4 thematic programme of the University of Debrecen.

Conflicts of Interest: The authors declare no conflict of interest.

\section{Nomenclature}

Nomenclature

$\mathrm{A}_{\mathrm{pv}}$

$\mathrm{C}_{\mathrm{pv}}$

G

$\mathrm{h}_{\text {conv }}$

$h_{\text {Force }}$

$h_{\text {Free }}$

$\mathrm{m}_{\mathrm{pv}}$

$\mathrm{P}_{\mathrm{PV}}$

Qconv

$\mathrm{Q}_{\text {conv,E }}$

$\mathrm{Q}_{\mathrm{lw}, \text { down }}$

Qlw,down,E

Q lw,total

$Q_{\text {lw,total,E }}$

$\mathrm{Q}_{\mathrm{lw}, \text { up }}$

$\mathrm{Q}_{\mathrm{lw}, \mathrm{up}, \mathrm{E}}$

Qrem

$\mathrm{Q}_{\text {rem,E }}$

$\mathrm{Q}_{\mathrm{sw}}$

$\mathrm{Q}_{\mathrm{sw}, \mathrm{E}}$

$\mathrm{T}_{\mathrm{amb}}$

$\mathrm{T}_{\text {ground }}$

$\mathrm{T}_{\text {module }}$

$\mathrm{T}_{\text {sky }}$

$\mathrm{v}_{\text {wind }}$

$\mathrm{W}_{\mathrm{pv}}$

Greek letters

$\alpha$

$\varepsilon_{\text {ground }}$

$\varepsilon_{\text {module }}$

$\varepsilon_{\text {sky }}$

$\sigma$

Subscripts

Levelized cost of electricity

PV

TMPS
$\mathrm{PV}$ module surface area $\left(\mathrm{m}^{2}\right)$

Module heat capacity $(\mathrm{J} /(\mathrm{kgK}))$

Incoming solar irradiance $\left(\mathrm{W} / \mathrm{m}^{2}\right)$

Overall convection coefficient $\left(\mathrm{W} /\left(\mathrm{m}^{2} \mathrm{~K}\right)\right)$

Forced convection coefficient $\left(\mathrm{W} /\left(\mathrm{m}^{2} \mathrm{~K}\right)\right)$

Free convection coefficient $\left(\mathrm{W} /\left(\mathrm{m}^{2} \mathrm{~K}^{3 / 2}\right)\right)$

Mass of PV module $(\mathrm{kg})$

PV output power (W)

Convective heat transfer on PV module (W)

Convective energy exchange for the PV module (Ws)

Emitted long-wave radiation at the bottom of the module surface (W)

Net long-wave radiation at the bottom of the module surface (Ws)

Total emitted long-wave radiation at the module surface (W)

Total net long-wave radiation at the module surface (Ws)

Emitted long-wave radiation at the top of the module surface (W)

Net long-wave radiation at the top of the module surface (Ws)

Remaining heat on PV module (W)

Remaining heat energy on PV module (Ws)

Effective irradiation on PV module (W)

Net rate short-wave energy exchange at module $(\mathrm{Ws})$

Ambient (air) temperature (K)

Ground temperature (K)

$\mathrm{PV}$ module temperature $(\mathrm{K})$

Sky temperature (K)

Wind speed $(\mathrm{m} / \mathrm{s})$

PV energy output (Ws)

PV module absorptivity (-)

Emissivity of surface of ground (-)

Emissivity of the PV module (-)

Emissivity of the sky dome (-)

Stefan-Boltzmann's constant $\left(=5.669 \times 10^{-8} \mathrm{~W} /\left(\mathrm{m}^{2} \mathrm{~K}^{4}\right)\right)$

LCOE (-)

Photovoltaic (-)

True Maximum Point Seeking (-) 


\section{References}

1. Zsiborács, H.; Pályi, B.; Pintér, G.; Popp, J.; Balogh, P.; Gabnai, Z.; Pet̋, K.; Farkas, I.; Baranyai, N.H.; Bai, A. Technical-economic study of cooled crystalline solar modules. Sol. Energy 2016, 140. [CrossRef]

2. Roth, W. General Concepts of Photovoltaic Power Supply Systems; Fraunhofer Institute for Solar Energy Systems ISE: Freiburg, Germany, 2005; pp. 1-23.

3. Fraunhofer Institute for Solar Energy Systems. ISE Photovoltaics Report; ISE: Freiburg, Germany, 2017; pp. 1-45.

4. Sawin, J. Renewable Energy Policy Network for the 21st Century Renewables 2017 Global Status Report; REN21 Secretariat: Paris, France, 2017; pp. 1-302.

5. Bai, A.; Popp, J.; Balogh, P.; Gabnai, Z.; Pályi, B.; Farkas, I.; Pintér, G.; Zsiborács, H. Technical and economic effects of cooling of monocrystalline photovoltaic modules under Hungarian conditions. Renew. Sustain. Energy Rev. 2016, 60. [CrossRef]

6. Cucchiella, F.; D'Adamo, I.; Gastaldi, M. Economic Analysis of a Photovoltaic System: A Resource for Residential Households. Energies 2017, 10, 814. [CrossRef]

7. Leccisi, E.; Raugei, M.; Fthenakis, V. The Energy and Environmental Performance of Ground-Mounted Photovoltaic Systems-A Timely Update. Energies 2016, 9, 622. [CrossRef]

8. Benick, J.; Richter, A.; Muller, R.; Hauser, H.; Feldmann, F.; Krenckel, P.; Riepe, S.; Schindler, F.; Schubert, M.C.; Hermle, M.; et al. High-Efficiency n-Type HP mc Silicon Solar Cells. IEEE J. Photovolt. 2017, 7, 1171-1175. [CrossRef]

9. Cosme, I.; Cariou, R.; Chen, W.; Foldyna, M.; Boukhicha, R.; Roca i Cabarrocas, P.; Lee, K.D.; Trompoukis, C.; Depauw, V. Lifetime assessment in crystalline silicon: From nanopatterned wafer to ultra-thin crystalline films for solar cells. Sol. Energy Mater. Sol. Cells 2015, 135, 93-98. [CrossRef]

10. Green, M.A.; Emery, K.; Hishikawa, Y.; Warta, W.; Dunlop, E.D. Solar cell efficiency tables (version 48). Prog. Photovolt. Res. Appl. 2016, 24, 905-913. [CrossRef]

11. Green, M.A.; Hishikawa, Y.; Dunlop, E.D.; Levi, D.H.; Hohl-Ebinger, J.; Ho-Baillie, A.W.Y. Solar cell efficiency tables (version 51). Prog. Photovolt. Res. Appl. 2018, 26, 3-12. [CrossRef]

12. International Energy Agency. International Energy Agency Technology Roadmap Solar Photovoltaic Energy, 2014th ed.; International Energy Agency: Paris, France, 2014; pp. 1-60.

13. Krempasky, J. Semiconductors, Questions and Answers; Technical Publishing House: Budapest, Hungary, 1977.

14. Panasonic Corporation. Solar Cell Achieves World's Highest Energy Conversion Efficiency of $25.6 \%$ at Research Level. Available online: http:/ /news.panasonic.com/global/press/data/2014/04/en140410-4/ en140410-4.html (accessed on 20 February 2018).

15. Verlinden, P.; Deng, W.; Zhang, X.; Yang, Y.; Xu, J.; Shu, Y.; Quan, P.; Sheng, J.; Zhang, S.; Bao, J. Strategy, development and mass production of high-efficiency crystalline Si PV modules. In Proceedings of the 6th World Conference on Photovoltaic Energy Conversion, Kioto, Japan, 24-27 November 2014.

16. Zsiborács, H.; Pályi, B.; Baranyai, H.N.; Veszelka, M.; Farkas, I.; Pintér, G. Energy performance of the cooled amorphous silicon photovoltaic (PV) technology. Idojaras 2016, 120, 415-430.

17. Kondo, M.; Yoshida, I.; Saito, K.; Matsumoto, M.; Suezaki, T.; Sai, H.; Matsui, T. Development of Highly Stable and Efficient Amorphous Silicon Based Solar Cells. In Proceedings of the 28th European Photovoltaic Solar Energy Conference, Villepinte, France, 30 September-4 October 2013; pp. 2213-2217. [CrossRef]

18. Cornaro, C.; Renzi, L.; Pierro, M.; Di Carlo, A.; Guglielmotti, A. Thermal and Electrical Characterization of a Semi-Transparent Dye-Sensitized Photovoltaic Module under Real Operating Conditions. Energies 2018, 11, 155. [CrossRef]

19. Chandrasekar, M.; Rajkumar, S.; Valavan, D. A review on the thermal regulation techniques for non integrated flat PV modules mounted on building top. Energy Build. 2015, 86, 692-697. [CrossRef]

20. Skoplaki, E.; Palyvos, J.A. Operating temperature of photovoltaic modules: A survey of pertinent correlations. Renew. Energy 2009, 34, 23-29. [CrossRef]

21. Skoplaki, E.; Palyvos, J.A. On the temperature dependence of photovoltaic module electrical performance: A review of efficiency/power correlations. Sol. Energy 2009, 83, 614-624. [CrossRef]

22. Alami, A.H. Effects of evaporative cooling on efficiency of photovoltaic modules. Energy Convers. Manag. 2014, 77, 668-679. [CrossRef] 
23. Radziemska, E.; Klugmann, E. Thermally affected parameters of the current-voltage characteristics of silicon photocell. Energy Convers. Manag. 2002, 43, 1889-1900. [CrossRef]

24. Krauter, S. Increased electrical yield via water flow over the front of photovoltaic panels. Sol. Energy Mater. Sol. Cells 2004, 82, 131-137. [CrossRef]

25. Abdolzadeh, M.; Ameri, M. Improving the effectiveness of a photovoltaic water pumping system by spraying water over the front of photovoltaic cells. Renew. Energy 2009, 34, 91-96. [CrossRef]

26. Calise, F.; Figaj, R.; Vanoli, L. Experimental and Numerical Analyses of a Flat Plate Photovoltaic/Thermal Solar Collector. Energies 2017, 10, 491. [CrossRef]

27. First Solar. First Solar Series $4^{\mathrm{TM}}$ PV Module-Advanced Thin Film Solar Technology. Available online: http:/ / www.firstsolar.com/-/media/First-Solar/Technical-Documents/Series-4-Datasheets/Series4V3-Module-Datasheet.ashx (accessed on 29 March 2018).

28. Jones, A.D.; Underwood, C.P. A thermal model for photovoltaic systems. Sol. Energy 2001, 70, 349-359. [CrossRef]

29. Yang, H.; Zhou, W.; Lu, L.; Fang, Z. Optimal sizing method for stand-alone hybrid solar-wind system with LPSP technology by using genetic algorithm. Sol. Energy 2008, 82, 354-367. [CrossRef]

30. Tsai, H.-F.; Tsai, H.-L. Implementation and verification of integrated thermal and electrical models for commercial PV modules. Sol. Energy 2012, 86, 654-665. [CrossRef]

31. Tsai, H.-L. Design and Evaluation of a Photovoltaic/Thermal-Assisted Heat Pump Water Heating System. Energies 2014, 7, 3319-3338. [CrossRef]

32. Xu, G.; Deng, S.; Zhang, X.; Yang, L.; Zhang, Y. Simulation of a photovoltaic/thermal heat pump system having a modified collector/evaporator. Sol. Energy 2009, 83, 1967-1976. [CrossRef]

33. Zsiborács, H.; Weihs, P.; Trimmel, H.; Oswald, S.; Pályi, B. A Thermal Model for Monocrystalline Solar Modules. In Proceedings of the 22nd Workshop on Energy and Environment, Gödölllö, Hungary, 1-2 December 2016; pp. 1-28.

34. Van Helden, W.G.J.; van Zolingen, R.J.C.; Zondag, H.A. PV thermal systems: PV panels supplying renewable electricity and heat. Prog. Photovolt. Res. Appl. 2004, 12, 415-426. [CrossRef]

35. Santbergen, R.; van Zolingen, R.J.C. The absorption factor of crystalline silicon PV cells: A numerical and experimental study. Sol. Energy Mater. Sol. Cells 2008, 92, 432-444. [CrossRef]

36. Liu, B.Y.H.; Jordan, R.C. A Rational Procedure for Predicting The Long-Term Average Performance of Flat-Plate Solar-Energy Collectors with Design Data for the U. S., Its Outlying Possessions and Canada. Sol. Energy 1963, 7, 53-74. [CrossRef]

37. Schott, T. Operation temperatures of PV modules: A theoretical and experimental approach. In Proceedings of the EC Photovoltaic Solar Energy Conference, London, UK, 15-19 April 1985; pp. 392-396.

38. Acciani, G.; Falcone, O.; Vergura, S. Analysis of the thermal heating of poly-Si and a-Si photovoltaic cell by means of Fem. In Proceedings of the International Conference on Renewable Energies and Power Quality (ICREPQ'10), Granada, Spain, 13-15 April 2010; pp. 1-5.

39. Hodges, B. Heat Budget and Thermodynamics at a Free Surface: Some Theory and Numerical Implementation (Revision 1.0d) ED 1300 BH; University of Western Australia: Crawley, Australia, 1999.

40. Holman, J. Heat Transfer, 10th ed.; The McGraw Hill Companies: New York, NY, USA, 2010.

41. The American Society of Heating, Refrigerating and Air-Conditioning Engineers. 1989 ASHRAE Handbook: Fundamentals; ASHRAE: Atlanta, GA, USA, 1989; ISBN 9780910110570.

42. Anis, W.R.; Mertens, R.P.; van Overstraeten, R.J. Calculation of solar cell operating temperature in a flat plate PV array. In Proceedings of the Photovoltaic Solar Energy Conference, Athens, Greece, 17-21 October 1983; pp. 520-524.

43. Pratt, A.W. Heat Transmission in Buildings; Wiley: Hoboken, NJ, USA, 1981; ISBN 0471279714.

44. Palyvos, J.A. A survey of wind convection coefficient correlations for building envelope energy systems' modeling. Appl. Therm. Eng. 2008, 28, 801-808. [CrossRef]

45. Haber, I.E.; Farkas, I. Numerical determination of the heat transfer of free standing solar modules. In Proceedings of the Seventh International Conference on Engineering Computational Technology, Valencia, Spain, 14-17 September 2010; Civil-Comp Press: Valencia, Spain, 2010; pp. 1-13.

46. Haber, I.; Farkas, I. Monitoring the energy properties of photovoltaic modules. EEA Electroteh. Electron. Autom. 2012, 60, 13-18. 
47. Haber, I.; Farkas, I. Analysis of the air-flow at photovoltaic modules for cooling purposes. Pollack Period. 2012, 7, 113-121. [CrossRef]

48. Háber, I.E.; Kistelegdi, I.; Farkas, I. Investigation of the solar and wind energy usage of a positive energy factory. Teh. Vjesn. Gaz. 2014, 21, 1243-1248.

49. Haber, I. Energy Modelling of Phoptovoltaic and Photovoltaic-Thermal Systems. Ph.D. Thesis, Szent István University, Gödölllő, Hungary, 2016.

50. Wang, Z.; Li, Y. Layer pattern thermal design and optimization for multistream plate-fin heat exchangers-A review. Renew. Sustain. Energy Rev. 2016, 53, 500-514. [CrossRef]

51. Wang, Z.; Sundén, B.; Li, Y. A novel optimization framework for designing multi-stream compact heat exchangers and associated network. Appl. Therm. Eng. 2017, 116, 110-125. [CrossRef]

52. Wang, Z.; Li, Y. Irreversibility analysis for optimization design of plate fin heat exchangers using a multi-objective cuckoo search algorithm. Energy Convers. Manag. 2015, 101, 126-135. [CrossRef]

53. Xu, J.; Tang, J. Modeling and analysis of piezoelectric cantilever-pendulum system for multi-directional energy harvesting. J. Intell. Mater. Syst. Struct. 2017, 28, 323-338. [CrossRef]

54. Xu, J.; Tang, J. Linear stiffness compensation using magnetic effect to improve electro-mechanical coupling for piezoelectric energy harvesting. Sens. Actuators A Phys. 2015, 235, 80-94. [CrossRef]

55. Xu, J.W.; Liu, Y.B.; Shao, W.W.; Feng, Z. Optimization of a right-angle piezoelectric cantilever using auxiliary beams with different stiffness levels for vibration energy harvesting. Smart Mater. Struct. 2012, 21, 65017. [CrossRef]

56. Wei, Z.; Lim, T.M.; Skyllas-Kazacos, M.; Wai, N.; Tseng, K.J. Online state of charge and model parameter co-estimation based on a novel multi-timescale estimator for vanadium redox flow battery. Appl. Energy 2016, 172, 169-179. [CrossRef]

57. Wei, Z.; Tseng, K.J.; Wai, N.; Lim, T.M.; Skyllas-Kazacos, M. Adaptive estimation of state of charge and capacity with online identified battery model for vanadium redox flow battery. J. Power Sources 2016, 332, 389-398. [CrossRef]

58. Wei, Z.; Meng, S.; Tseng, K.J.; Lim, T.M.; Soong, B.H.; Skyllas-Kazacos, M. An adaptive model for vanadium redox flow battery and its application for online peak power estimation. J. Power Sources 2017, 344, $195-207$. [CrossRef]

59. Li, H.; Liu, Z.; Liu, K.; Zhang, Z. Predictive Power of Machine Learning for Optimizing Solar Water Heater Performance: The Potential Application of High-Throughput Screening. Int. J. Photoenergy 2017, 2017, 1-10. [CrossRef]

60. Breyer, C.; Schmid, J. Global Distribution of Optimal Tilt Angles for Fixed Tilted PV Systems. In Proceedings of the 25th European Photovoltaic Solar Energy Conference and Exhibition/5th World Conference on Photovoltaic Energy Conversion, Valencia, Spain, 6-9 September 2010; pp. 4715-4721.

61. Santbergen, R.; Rindt, C.C.M.; Zondag, H.A.; van Zolingen, R.J.C. Detailed analysis of the energy yield of systems with covered sheet-and-tube PVT collectors. Sol. Energy 2010, 84, 867-878. [CrossRef]

62. Szúcs, I. Applied Statistics; Agroinform Publishing Office: Budapest, Hungary, 2002.

(C) 2018 by the authors. Licensee MDPI, Basel, Switzerland. This article is an open access article distributed under the terms and conditions of the Creative Commons Attribution (CC BY) license (http://creativecommons.org/licenses/by/4.0/). 